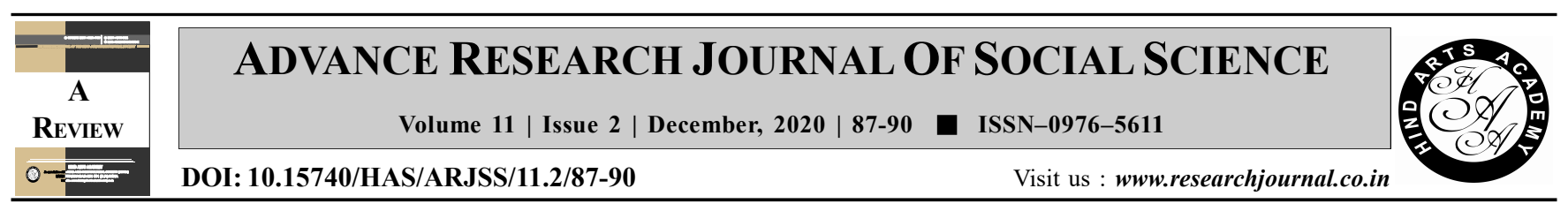

\title{
Analysing the role of Kollam Port in the maritime intercourse of Kerala
}

\author{
H. Adabiya
}

P.G Department of History, Iqbal College, Peringammala, Thiruvananthapuram (Kerala) India

(Email: adabiyaiqbal@gmail.com)

\section{ARTICLE INFO :}

$\begin{array}{lll}\text { Received } & : & 15.09 .2020 \\ \text { Accepted } & : & 05.11 .2020\end{array}$

\section{KEY WORDS :}

Maritime relations, Emporium, Artefacts

\section{HOW TO CITE THIS ARTICLE :}

Adabiya, H. (2020). Analysing the role of Kollam Port in the maritime intercourse of Kerala. Adv. Res. J. Soc. Sci., 11 (2): 87-90, DOI: 10.15740/HAS/ARJSS/ 11.2/87-90.Copyright@2020:Hind AgriHorticultural Society

\begin{abstract}
Kerala had maintained active trade relations with countries of outside world from very ancient time onwards. Among the ancient Port of Kerala, Kollam or Quilon had enjoyed a prominent place from the remote past and has a long drawing attraction worldwide. It is an old sea Port town on the Arabian coast had a sustained commercial reputation from the days of Phoenicians and the Romans. The spices which produced Kollam had great demand in oriental world. Early Christian and Arab travellers spoke very high of Kollam and its commercial significance. The Kollam was one of the most important Ports in the east west trade of the Indian Ocean. The present paper seeks to analyse the space of Kollam in the maritime relations of Kerala. In 2014 the Port trust had discovered thousands of Chinese coins and Stone Age weapons from the Kollam Port, which is revealing the amazing historic background and trade culture of the Port city. This is first time that these much of artefacts are getting from a Port in India. The emergence of antiques from Kollam Port area reveals that Kollam was the most famous Port city in India which served as the business hub of people from China, Middle East, Dutch, Portugal, Brazil and other Eastern Mediterranean Countries. The archaeologists believe that there is an engulfed city in the seabed of current Kollam Port. It is an established fact that Kollam was a repository of all sorts of conceivable commercial centre. For a long time and today Kollam was famous as an emporium of the east.
\end{abstract}

